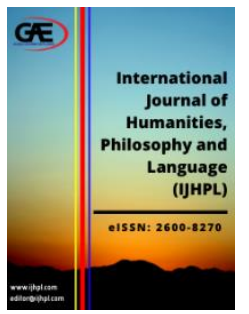

\author{
INTERNATIONAL JOURNAL OF \\ HUMANITIES, PHILOSOPHY \\ AND LANGUAGE \\ (IJHPL) \\ www.ijhpl.com
}

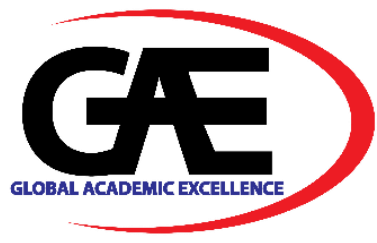

\title{
THE ATTITUDE OF MOTHERS IN REVITALIZING PUNJABI LANGUAGE: A CASE STUDY OF THE PUNJABI COMMUNITY IN MANJUNG DISTRICT, PERAK
}

\author{
Deepa a/p Visvanathan ${ }^{1}$
}

1 Faculty of Arts and Social Science, Department of Languages and Linguistics, Universiti Tunku Abdul Rahman (UTAR), Malaysia

Email: deepav@utar.edu.my

\section{Article Info:}

Article history:

Received date: 17.05.2021

Revised date: 23.05.2021

Accepted date: 01.09.2021

Published date: 07.09.2021

\section{To cite this document:}

Visvanathan, D. (2021). The Attitude of Mothers in Revitalizing Punjabi Language: A Case Study of The Punjabi Community in Manjung District, Perak. International Journal of Humanities, Philosophy and Language, 4 (15), 21-34.

DOI: $10.35631 /$ IJHPL.415003.

This work is licensed under CC BY 4.0

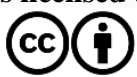

\begin{abstract}
:
Punjabi is a small minority community in Malaysia among the approximately two million Indians in Malaysia. Punjabi people remain distinct from other people of Indian origins because of their religious beliefs and a strong sense of community. In the context of Malaysia, studies about the Punjabi community have not been encouraging and very minimal. As the Punjabi in Malaysia becomes more educated, the Punjabi community, which has long been undergoing a gradual shift into modern Malaysian society, and less emphasis is being placed on the ability to read and write Punjabi. The aim of this study is to obtain an overview of the language use patterns and language attitudes of Malaysian Punjabi mothers with the presence of their children. Specifically, the objective is to shed light on the importance of promoting Punjabi in the home domain by investigating whether the education and attitude of the mothers bring on the value of speaking the Punjabi language to their children in the home domain. A total of 11 respondents aged between 25 and 44 with children at or within the age of 6 were interviewed. One of the most significant findings of this study is the mismatch between language attitudes and actual language use by mothers with their children. The awareness exists in the mothers that Punjabi is important to their children to communicate with old age people and the Punjabi language is being used to do their prayers and to read their holy book. However, this positive attitude towards the language is not reflected in their language use and choice regardless of their education level. English dominated in most instances and most of the mothers claimed to be more comfortable speaking to their children in English.
\end{abstract}

Keywords:

Language Revitalization, Language Attitudes, Minority, Punjabi Mothers, Home Domain 


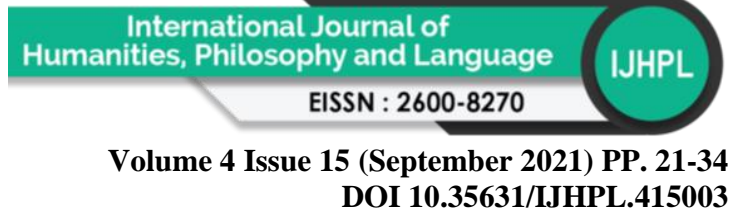

\section{Introduction}

\section{Background to The Study}

Malaysia is a country with rich and unique linguistics situation. English is the lingua franca among the general population and the functional language in the government and public sectors while the three ethnic languages represent the three ethnic communities, with Malays as the ceremonial national language. But there is another minority community in Malaysia known as Punjabi. The Joshua Project (2021) reports that Punjabi are a small minority among the approximately two million Indians in Malaysia. Punjabi people remain distinct from other people of Indian origins because of their religious beliefs and strong sense of community.

As the Punjabi in Malaysia becomes more educated, this study focuses on the Punjabi community, which has long been undergoing a gradual shift into modern Malaysian society and less emphasis is being place on the ability to read and write Punjabi that leads to language shift and has the status of minority language (Mukherjee, 2003). As rightly argued by Holmes (2017), language shifts mostly occur when a less dominant group "shifts towards the language of the dominant powerful group in the community". As the dominant group of speakers has little or less 'incentive' to use the language from the minority group. To further add, as stated by Holmes (2017), people in the community itself regard the dominant language as a symbol of 'status, prestige and social success'. This somehow portrays the minority language as less important and lack of societal demands by their own community. Furthermore, Mukherjee (2003) and David (2005) added that this may be due to societal demand of the new era of globalization. For example, globalization has encouraged many Malaysians to focus on the English language as it is an international language to meet employability.

The discussion on language maintenance is a central issue for a minority language group. Holmes, (2017) said that language maintenance occurs when 'the language is considered an important symbol of a minority group's identity, to preserve their own ethnic identity. Therefore, the need to maintain the language is to keep the identity much longer particularly in migration. Polish people, for example, view the importance of preserving their language although they have migrated to another country in which they maintained the language for three to four generations. There are several ways in which the language is maintained such as 'living close to each other among the minorities', 'frequency of contact with the homeland', 'discouragement of intermarriage', 'preserving the worship places' as well as 'institutional supports' are examples on how they maintain the language. However, the efforts on the part of the government in promoting Punjabi are predominantly in the domains of media and education. Without the interest of the speech community in revitalization, any effort to promote institutional protection would be egotistic and meaningless. Nevertheless, there are now 20 Punjabi Education Centers nationwide with more than 3000 students and 220 teachers. This is not feasible if there's no interest from the Punjabi community to revitalize their language. The time and effort put to build the Punjabi Education Centers must be complex and can only be done with immense efforts on which sociolinguists also agree on the complexity, immense effort, and high costs of language revitalization (Derhemi, 2002).

\section{Statement of The Problem}

An analysis by the Joshua Project (2021) team, the Punjabi community, which has long been undergoing a gradual shift into modern Malaysian society and less emphasis, is being place on the ability to read and write Punjabi. The efforts on the part of the government in promoting 


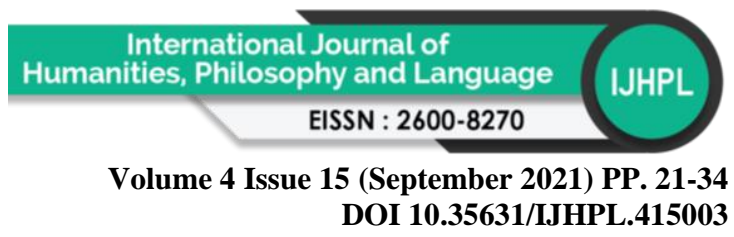

Punjabi are predominantly in the domains of media and education. As stated by David, Naji, \& Kaur (2003), there are now 20 Punjabi Education Centers nationwide with more than 3000 students and 220 teachers. But still there is little or no attention paid to the home domain and the language attitudes of the interlocutors, namely, the mother, in the home domain (Naganandhini, 2011).

Women of different ages happened to have some influence on their language choice and have affected their language behavior in the home domain. On the other note, there's a difference in language behavior between women of different ages. Mukherjee (2003) reported that older Punjabi women who did not work had a higher rate of maintaining the Punjabi language as compared to younger women who are pursuing a professional career. She further added that the older Punjabi women has a sense of pride in maintaining their linguistic heritage. In this regard, this study is an attempt to determine whether education level of mother influences the value of speaking to children in Punjabi language.

Regardless of the age, these older and younger women's language input at the home domain plays an important role in a child's language development. As rightly argued by Naganandhini (2011), a child's language ability can be developed when the mother tongue is spoken at the home domain in which the mother's language use will have a distinct effect on the child's language development and language behavior in the home domain. Hence, this study chose to focus on the mother's language input as opposed to the father's or entire family domain to investigate the attitude of mothers to promote Punjabi language.

A language is said to be dead when there are no more speakers of that language (Crystal, 2000). This, of course, does not mean the death of the speakers themselves. Nor do languages disappear to leave a linguistics vacuum; they are replaced by another language (Fase, Jaspeart, \& Kroon, 1992). Janse, M., Tol, S., \& Hendriks, V. (2003) pointed out that the gradual disappearance of a language usually begins with children. He further explains that a language can be said to be potentially endangered when a section of the younger population starts giving preference to another language, which would gradually and ultimately lead them forgetting their own. This can be evident when Mukherjee (2003) reported the language used by the participant's grandchildren who have third-generation Malaysian-Punjabi parents, do not speak Punjabi fluently, as both their parents speak to each other mostly in English. Tsunoda (2005) also places stress on lack of language transmission to children in an education; or domestic setting as one of the factors for language death.

\section{Research Objectives}

The aim of this study is to obtain an overview of the language use patterns and language attitudes of Malaysian Punjabi mothers with the presence of their children. Specifically, the objectives are as follows: -

a) To investigate the attitude of the mother to promote Punjabi language in the home domain.

b) To investigate whether education of mothers brings on the value of speaking to children in Punjabi language. 


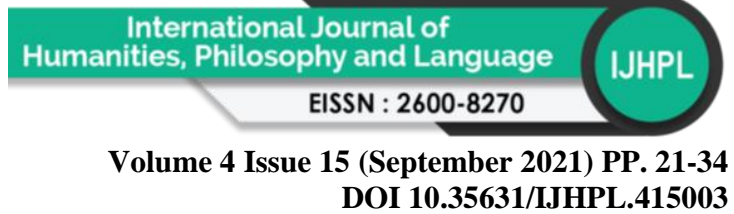

\section{Literature Review}

\section{Statistics of Malaysian Punjabi Community}

More than 100 million people worldwide speak different dialects of Punjabi language as their first language. In Malaysia, based on 2016 statistics, 6.4\% of Malaysia's estimated population is Indians. The Indian community in Malaysia is the smallest of the three main ethnic groups, with the other two groups which are Malay and Chinese. Estimates of $75 \%$ of Indians are made up by Tamils and other Indian communities in Malaysia include the Telegu, Malayalee, Punjabi, Sindhi and Benggali (The Malaysian Administrative Modernisation and Management Planning Unit, 2021).

There is a host of a smaller minority groups, one of which is the Punjabi--Sikh community. In the 1999 census, the Punjabi in Malaysia numbered 46,800 equal to around 15\% of the Indian community and they consist of mostly Hindi-speaking Punjabis (Gill S. K., 2014). Until present, there are approximately sixty-eight thousand Punjabi in Malaysia (Joshua Project, 2021)

They first came to Malaysia in the 19th century as British political prisoners. A second wave was brought in by the British to serve as policemen for the British Straits Settlement communities and as night watchmen for industries. Punjabi are a small minority among the approximately two million Indians in Malaysia. They have preserved a distinct Punjabi/Sikh identity within Malaysian society that sets them apart from the Tamil and other Indian communities that are Hindu.

\section{Language Shift and Language Maintenance}

Pauwels (2016) defined language shift as a process of replacing one language with another as the means of communication and socialization at both an individual and community level. He further argued that language shift is both a process and an outcome. Both situations result in favoring the use of a dominant language, which leads to the loss of first language. In line with this, the rate and speed of the shift varies among different communities and the most dramatic outcome is language loss or language death. To add on this, Clyne (2003) mentioned that language shift is a process because the shift from first language to a dominant language in a community occurs gradually over several generations of speakers. However, the language shift is most likely slower among communities in which minority language is 'highly valued' (Holmes, 2017).

Language maintenance is the process by which languages continue to be spoken by a particular speech community "in the face of competition from a regionally and socially powerful or numerically stronger language" (Mesthrie, 1999, p.42). In some cases, a few speakers in the community enter a new linguistics environment but continue to use their first language in all domains. Usually, the speech community becomes bilingual, adapting to the use of both the first language and the 'more powerful/stronger' language in the new environment for wider communication to take place. Language maintenance continues to occur in such a speech community despite a reduction in the number of domains in which the first language remains in use. In recent literature, some scholars have used the term 'language revitalisation' rather than language maintenance (Hale, 1992; Sallabank, 2013). The terms have similarities, but language revitalisation involves a more intense process depending on the first language's state of endangerment (Pauwels, 2016). 


\section{Minority Language}

The term 'minority language' can serve several definitions of concepts depending upon several contexts. In 1958, The Supreme Court of India proposed a parameter in which defining a 'minority language' as "the language of the minority community" (i.e., a community numerically less than 50 per cent), as cited by Pandharipande (2002). This is according to the Constitution of India which identifies eighteen languages regarded as "scheduled languages" whereby those which are not included in the category are considered as "non-scheduled languages". The "non-scheduled languages" are what have been classified as the "minority languages' in the country. A minority language can also be viewed as the language used by less than 50 per cent of the total population of a state and this language is 'different from the language of the majority community and the language of the state'. Chaklader (1981, p. 14).

Another parameter which defines the minority language is in term of power. It is noted that languages which lack in 'political, economic or cultural power' most likely regarded as minority language of the community, Pandharipande (2002). The positive efforts to use the minority language in particular community may assist the speakers of the language to maintain their own language, (Holmes, 2017). As further elaborated by Holmes (2017), this effort may also protect the minority language speakers 'to resist the pressure from the majority group to switch to their language'. On a different perspective, a minority language with high status may have the advantage to maintain the language particularly with the minority language which achieves 'international statuses. Languages, such as, French, Greek and Spanish, as example, achieve this recognition as these languages somehow have contributed much to the Western philosophy and cultures. Hence, the number of speakers who speak the language may somehow contribute towards the resistance of shift into the dominant language although this is somewhat due to special concerns by the society as well (Holmes, 2017). 


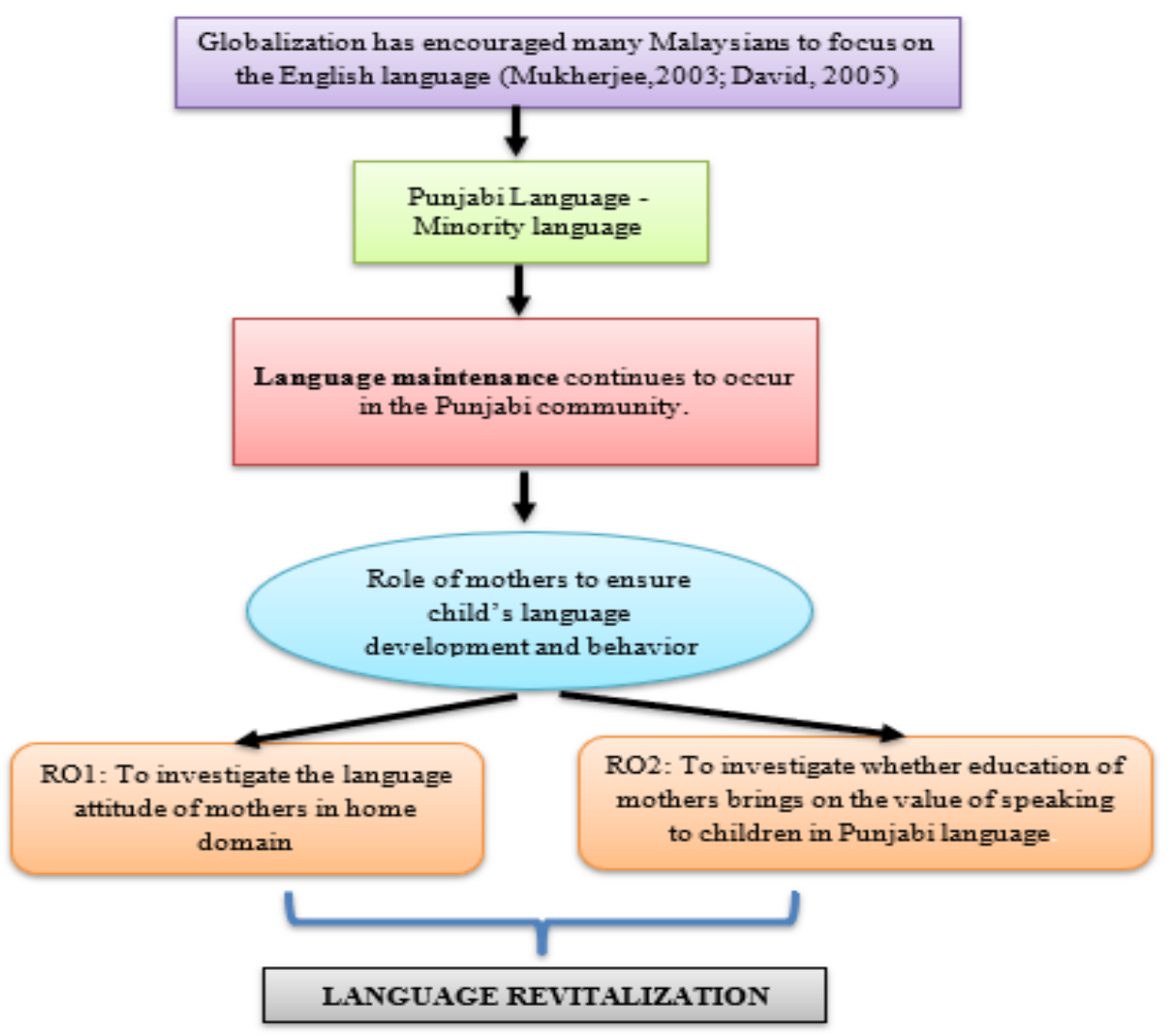

\section{Figure 1: The Conceptual Framework of The Study}

\section{Methodology}

\section{Research Design}

Since this study aims to obtain a general overview of the language use patterns of Malaysian Punjabi mothers with or in the presence of their children and their language attitudes in the home domain, this study used a case study research and qualitative approach. A case study approach is unique to qualitative research due to its flexibility and ability to frame an in-depth and detailed examination of a phenomenon such as a program, a group, an institution, a community, or a specific policy within a bounded system. It relies on multiple sources of evidence such as documents, interviews, archival records, and observations (Yin, 2003). On a practical level, a qualitative approach meets the needs and aims of the present study. The qualitative approach enables a researcher to view and observe the social problem through the eyes of the participants (Denzin \& Lincoln, 2000) in their local contexts (Flick, 2014). The social problem being examined and analysed is Punjabi community language revitalization in Manjung District, Perak.

\section{Data Collection}

\section{Structured Interview}

A structured interview session was conducted to elicit information about their language use patterns with and in the presence of the child, mothers' language attitudes when it comes to the language choice with their children. The structured interview questions were adapted from a Copyright $\odot$ GLOBAL ACADEMIC EXCELLENCE (M) SDN BHD - All rights reserved 


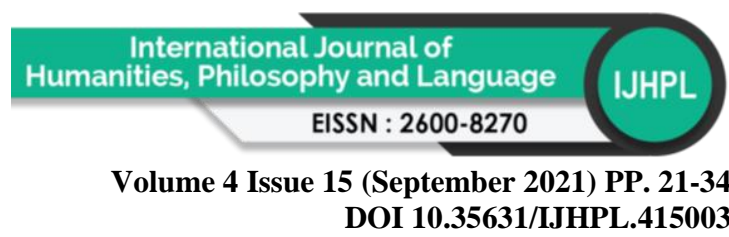

questionnaire in Naganandhini's (2011) study entitled "Amma" or "Mommy": The Role of Mothers in Facilitating Intergenerational; Language Transmission in the Singaporeans Tamil Community". The structured interview session contained 4 parts with a total of 15 questions. Part A consist of 5 questions, to obtain information on the direct language input from mother to child where the mothers had to rate their language use with the child, in various domains such as in conversation, reading, storytelling and watching television. A scale of 5 was used for the ratings, with 5 for the highest usage and 1 for the least usage. Part B: also consist of 5 questions, to investigate the indirect language input in the form of language use with other people in the presence of the child, also using a scale of 5. Parts $\mathrm{C}$ required them to state and justify the language they would use instinctively and spontaneously in 3 different situations such as when the child is about to fall or touch something hot, or when the child has done something wrong, or when the child has done well in school. Part D contained a couple of open-ended questions asking about the value they accord to the Punjabi language in the lives of their children and whether they make a conscious effort in speaking in Punjabi to them.

\section{Sampling Technique}

For this study, decisions related to sampling need to be based on what the researcher wants to explore (Wai See Ong, 2019). A purposeful sampling strategy was adopted when selecting the participants. A total of 11 Malaysian-Punjabi mothers who have children at or below the age of 6 were selected as participants for the study. This age gap of the children was chosen because they belong to the end of critical age for language development (Hoff, 2005; Flynnv \& Manuel, 1991). Gleitman, Newport, \& Gleitman (1984) observed that mothers' language input has the most effect in younger children. Moreover, with older children, there is the possibility that language use patterns with their parents are more influenced by the language behavior picked up from school. Hence, the age of the children was capped at the stage when they have not begun full time schooling. The respondents were aged between 30 to 50 . The largest age group composed of those in the $41-50$ ( 8 respondents), followed by 3 respondents in the range of $31-40$.

The mothers were educated with SPM qualification minimum, and a few were working adults, 4 were teachers, 2 were headmistresses in a school, 1 worked as a secretary in a company and remaining 4 were housewives with SPM qualification. The women claimed to be proficient in both English and Punjabi which claimed higher proficiency in English than in Punjabi, but only 1 respondent, headmistresses who claimed to have the matriculation education in India and claimed higher proficiency in Punjabi than in English. All the women were born in Malaysia except for one who were born in India but had settled down in Malaysia and have been living in Perak, Malaysia for 37 years.

\section{Data Analysis}

Content analysis approach was used to analyze the data obtained in this study. Content analysis is a type of data analysis and is defined as "a systematic coding and categorizing approach" (Grbich, 2013, p.190). Since all questions were structured, the responses were recorded manually during the interview session. The researcher tabulated the frequency for the highest usage and for the least usage for each domain in Part A and Part B. The scale: 1 - Least Usage, 2- Limited Usage, 3 - Neutral, 4 - Moderate Usage, 5- Highest Usage were used during the coding process to evaluate the language attitude of Punjabi mothers in different home domain. 


\section{Results and Discussion}

The ratings for each domain in Part A and Part B were tabulated and the answers to the openended questions were summarized. To begin with, the total number of respondents for the highest usage of both English and Punjabi language for each domain in Part A was calculated and the findings have been presented in the Table 1 below.

Table 1. Part A: Language Use Patterns in Direct Input

\begin{tabular}{|l|c|c|}
\hline \multirow{2}{*}{ Instances } & \multicolumn{2}{c|}{ Highest Usage } \\
\cline { 2 - 3 } & English & Punjabi \\
\hline Direct Conversation at home & $\mathbf{6 / 1 1}$ & $1 / 11$ \\
\hline Direct Conversation outside home & $\mathbf{5 / 1 1}$ & $2 / 11$ \\
\hline Reading & $\mathbf{5 / 1 1}$ & $1 / 11$ \\
\hline Television & $\mathbf{4 / 1 1}$ & $3 / 11$ \\
\hline Storytelling & $\mathbf{5 / 1 1}$ & $1 / 11$ \\
\hline
\end{tabular}

Table 1 above shows the distribution of total number of respondents who have rated the highest usage of both English language and Punjabi language during direct conversation at home, outside home, reading, watching television and storytelling. It can be clearly seen that English language takes precedence in every given situation. In their direct conversations with their children, mothers have indicated their use of English to be higher when they are at home and this domain seems to have the highest rating of all the other domains listed. The domain of watching television had the highest usage of the Punjabi language, followed by the domain of having the direct conversation outside home and finally there are at least one respondent who had used the Punjabi language the highest in the domain of having the direct conversation at home, reading and storytelling. From the result above, it is evident that children are not exposed to the language frequently. The result above can indicate that the children get very low Punjabi literary input from their mothers. Children get lesser exposure to Punjabi language in the storytelling domain then in in the television domain.

The following table shows the language use patterns in indirect input for Part B.

Table 2. Part B: Language Use Patterns in Indirect Input

\begin{tabular}{|l|c|c|}
\hline \multicolumn{1}{|c|}{ Instances } & \multicolumn{2}{c|}{ Highest Usage } \\
\cline { 2 - 3 } & English & Punjabi \\
\hline Conversation with spouse in the presence of the child & $5 / 11$ & $3 / 11$ \\
\hline $\begin{array}{l}\text { Conversation with parents or parents-in-law in the presence } \\
\text { of the child }\end{array}$ & $1 / 11$ & $5 / 11$ \\
\hline $\begin{array}{l}\text { Conversation with child's Punjabi speaking friends in the } \\
\text { presence of the child }\end{array}$ & $4 / 11$ & $3 / 11$ \\
\hline Conversation with guests at home in the presence of the child & $3 / 11$ & $4 / 11$ \\
\hline Conversation with own friends in the presence of the child & $4 / 11$ & $4 / 11$ \\
\hline
\end{tabular}

The two instances where Punjabi language takes precedence as the language of choices are when the mother is talking to her parents/parents-in-law and followed by the instances when the conversation with guests who have come home. In all other contact situations in the presence of the child, English is the more dominant choice of language. The respondents use the most English language and least Punjabi language with their spouse and child's Punjabi 
Volume 4 Issue 15 (September 2021) PP. 21-34 DOI 10.35631/IJHPL.415003

speaking friends in the presence of the child. They have the most balanced usage of the two languages when they are in conversation with their own friends.

In Part $\mathrm{C}$, respondents were asked for their spontaneous language choice in given specific circumstances and their justification for it, the following findings in Table 3 were obtained.

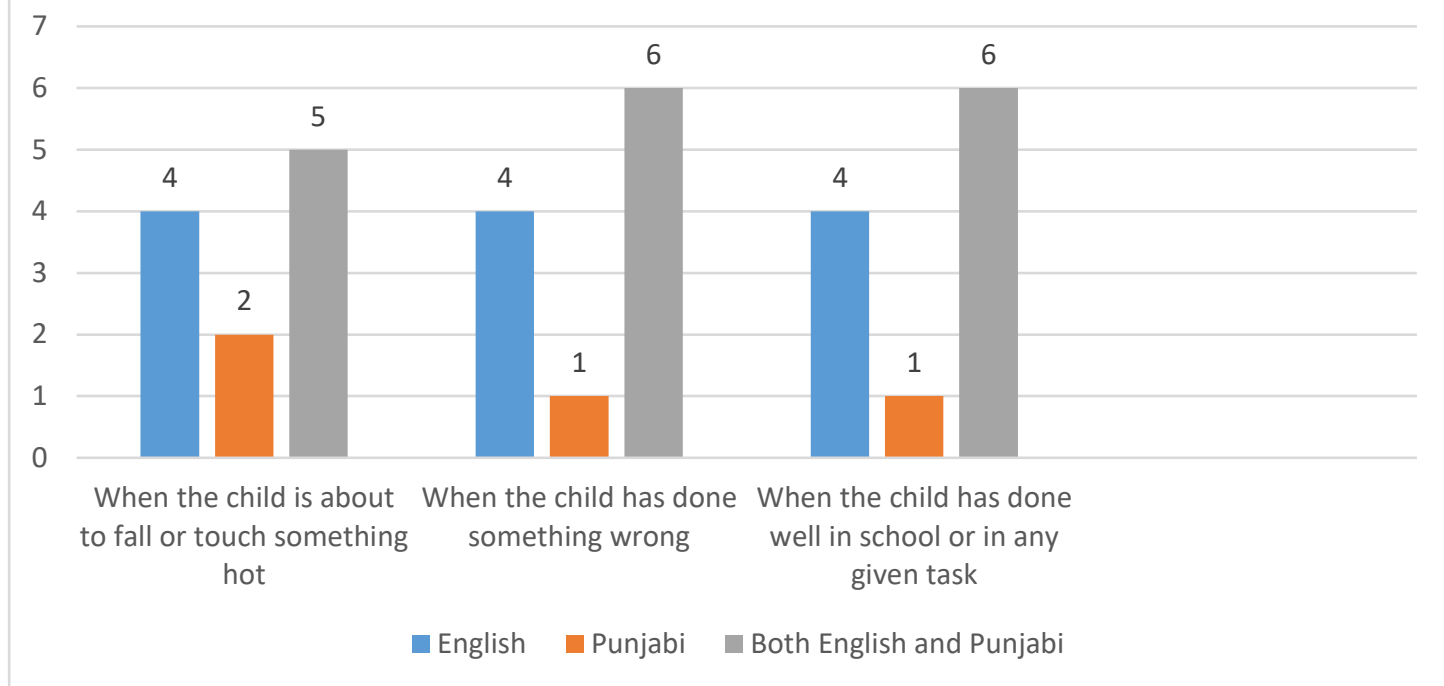

Figure 2: Part C: Spontaneous Language Choice in Specific Situations

The figure above shows an equal preference for English in all the 3 given situations. Nearly half of the respondents chose English language and Punjabi language as their spontaneous choice of language for all the situations. Punjabi language dominance is at the highest when the child is about to fall or touch something hot.

In Part D of the interview session, there were two open-ended questions that tested their language attitudes. When they were asked if they thought it was important for their child to be able to converse fluently in Punjabi, an impressive 10 out of the 11 respondents said yes, while 1 respondent was so hesitant and said no. Many who had said yes mentioned that since the language was their child's mother tongue, they felt he/she had to be fluent in it and had to do their part in preserving it. Some emphasized the importance of learning Punjabi language because it would help the children to communicate with old age people and recite mantras during prayers and most importantly to be able to read holy books. They believed that their children should not lose their mother tongue under any circumstance. The following are some of the responses obtained by mothers regarding their effort in making their children to converse in Punjabi language.

Table 3. Part D: Mothers' Conscious Effort in Making the Children to Converse in Punjabi Language

\begin{tabular}{|c|l|}
\hline Interviewee & $\begin{array}{l}\text { Responses obtained on their effort to converse in Punjabi language with } \\
\text { their children }\end{array}$ \\
\hline M1 & Yes, we are sending our children to Punjabi class. \\
\hline M2 & Yes, at times. \\
\hline M3 & Sometimes. \\
\hline M4 & Yes. \\
\hline
\end{tabular}


Volume 4 Issue 15 (September 2021) PP. 21-34

DOI 10.35631/IJHPL.415003

\begin{tabular}{|l|l|}
\hline M5 & $\begin{array}{l}\text { Yes, we have Punjabi class conducted in Gurdwara Sahib. We even send them } \\
\text { to extra class do that they will be more fluent since the classes being } \\
\text { conducted once a week. }\end{array}$ \\
\hline M6 & Yes. \\
\hline M7 & Yes. \\
\hline M8 & Yes, I do my best at least a few words a day. \\
\hline M9 & Trying to. \\
\hline M10 & Yes. \\
\hline M11 & No. Already a habit to communicate in English. \\
\hline
\end{tabular}

\section{Discussion on Research Objective 1}

\section{Does The Language Attitude of The Mothers Promote Punjabi Language in The Home Domain?}

One of the most significant findings of this study is the mismatch between language attitudes and actual language use by mothers with their children. The awareness exists in the mothers that Punjabi language is important to their children to communicate with old age people and Punjabi language is being used to do their prayers and to read their holy book. However, this positive attitude towards the language is not reflected in their language use and choice. English dominated in most instances and most of the mothers were noted to have claimed to be more comfortable speaking to their child in English.

Hence the generation of mothers in this current study grew up through an era of rapidly lessening domains for the Punjabi language, bounded by more and more English language. This might prove to be a possible clarification for the participants' claim of the lack of comfort and artlessness in Punjabi language usage. In other words, despite having a positive attitude towards the language, they are unable to use it as easily and comfortably as they use English language. This mismatch between language attitudes and actual language use could also be the result of a difference in the overt and covert language attitudes of the participants. The discussion of language attitudes has been traditionally correlated with the presence of two types of attitudes namely, overt and covert which would make an individual to make decision in his/her language choice (Chakrani, 2010). Considering this social phenomenon, the respondents in this study overtly, display a positive attitude towards Punjabi language and the value they accord to it, covertly they might be favoring English language instead.

\section{Discussion on Research Objective 2}

Does Education of Mothers Bring on The Value of Speaking in Punjabi Language? There was an interesting difference motivated by the educational level of the mothers upon analyzing the data. The table below summarizes the findings for the interview session, Part A based on the respondents' educational level.

Table 4. Distribution of Respondents' Education Level and Occupation

\begin{tabular}{|c|c|c|}
\hline Participants & Education Level & Occupation \\
\hline M1 & SPM & Housewife \\
\hline M2 & Degree & Secretary \\
\hline M3 & Degree & Teacher \\
\hline
\end{tabular}


Volume 4 Issue 15 (September 2021) PP. 21-34

DOI 10.35631/IJHPL.415003

\begin{tabular}{|c|c|c|}
\hline M4 & SPM & Housewife \\
\hline M5 & SPM & Housewife \\
\hline M6 & SPM & Punjabi Language Teacher \\
\hline M7 & SPM & Punjabi Language Teacher \\
\hline M8 & Degree & Teacher \\
\hline M9 & SPM & Housewife \\
\hline M10 & Matriculation (India) & Punjabi School Headmistress \\
\hline M11 & Matriculation (Malaysia) & Preschool Headmistress \\
\hline
\end{tabular}

Table 5. Respondents' Language Use Patterns for the Highest Usage of English and Punjabi in Direct Input by Education Level

\begin{tabular}{|c|c|c|c|c|c|c|c|c|}
\hline \multirow[t]{2}{*}{ Instances } & \multicolumn{2}{|c|}{ Bachelor's Degree } & \multicolumn{2}{|c|}{ SPM } & \multicolumn{2}{|c|}{ Matriculation } & \multicolumn{2}{|c|}{$\begin{array}{c}\text { Total Ratings for } \\
\text { Highest Usage }\end{array}$} \\
\hline & English & Punjabi & English & Punjabi & English & Punjabi & English & Punjabi \\
\hline $\begin{array}{l}\text { Direct } \\
\text { Conversation } \\
\text { at home }\end{array}$ & $\begin{array}{l}\text { M2, M3, } \\
\text { M8 }\end{array}$ & & $\begin{array}{l}\text { M4, } \\
\text { M9 }\end{array}$ & M1 & M11 & & $6 / 11$ & $1 / 11$ \\
\hline $\begin{array}{l}\text { Direct } \\
\text { Conversation } \\
\text { outside home }\end{array}$ & $\begin{array}{c}\text { M2, M3 } \\
\text { M8 }\end{array}$ & & M9 & M9 & M11 & M10 & $5 / 11$ & $2 / 11$ \\
\hline Reading & $\begin{array}{c}\text { M2, M3, } \\
\text { M8 }\end{array}$ & & M9 & & M11 & M10 & $5 / 11$ & $1 / 11$ \\
\hline Television & M3, M8 & & M9 & M1, M9 & M11 & M10 & $4 / 11$ & $3 / 11$ \\
\hline Storytelling & $\begin{array}{l}\text { M2, M3, } \\
\text { M8 }\end{array}$ & & M9 & & M11 & M10 & $5 / 11$ & $1 / 11$ \\
\hline
\end{tabular}

Based on the direct language input from the mother in the given instances, mothers who come from a non-university education background, SPM and Matriculation rated Punjabi much higher than the mothers from a university education background, bachelor's degree. In other words, these mothers use much more Punjabi with their children in general and in comparison, to English Language. Since there are three mothers have university education, the importance was given to the English language in most of the home domains and in comparison, to one participant who has an India Matriculation Education and Punjabi language is given emphasize more compared to English language in all the four domains (direct conversation outside home, reading, watching television and storytelling).

The most significant finding of this study was the role of education level in the language use patterns of our group of participants. Mothers who had SPM Education showed a more balanced usage of Punjabi and English. These mothers believed that it is important for the children to be able to speak fluently in both Punjabi language and English language at same time, except for one who has an India Matriculation Education, showed positive attitudes towards the Punjabi language, and showed a markedly larger gap in her usage of English and Punjabi. This could be the sense of belong and pride in using and promoting the Punjabi language in the home domain (Murkherjee, 2003). 


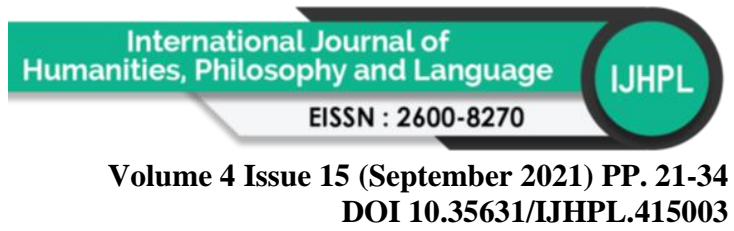

The spontaneous use of language in the home domain is important to determine a child's language ability. As rightly argues by Fishman (1991) the 'unplanned' and 'spontaneous' use of a language by a community is the real arena where a language changes, and the only means of measuring the efficacy of a language policy. There is extensive research to show the importance of mother's language input and the distinct effect their language use has on the child's language development and language behavior (Furrow, D., Nelson, K., \& Benedict, H.,1979; Hoff-Ginsberg, E., 1991; Tamis-LeMonda, \& Bornstein, 1997; Hoff. E. 2003; Baumwell; Hammer et al, 2011).

\section{Conclusion and Recommendations}

This study is done in the hope of bringing attention to the importance of the language attitudes prevalent in the home domain and the need for the education of parents on the value of speaking to their children in Punjabi. The results had shown a dominance of English in most domains and the conflict between the mother's language use patterns and their attitudes and educational level of the mothers seems to be a determining factor in their language choice. As rightly stressed by Fishman (1991) and Derhemi (2002), the need for new cases studies in this field is important to ensure that language choice in a community is always a social behavior, as well as other social phenomena related to the language in a community.

Exploration into just one aspect of the home domain, the mother's language input, has shown that in the Malaysian Punjabi community, the language is losing ground even in that core domain. This implies that more efforts must be impelled into encouraging and promoting the use of the mother tongue in the home and family domain. Therefore, recommendations for more attention need to be dedicated to studies on language attitudes and behavior of people in important settings such as the home, school or work and more research needs to be done to see if the same phenomenon is prevalent in the other ethnic communities as well.

\section{References}

Azharudin, M. D. (2002). Gerakan Politik di Tanah Melayu Pada Era Perang Dunia I Dengan Tumpuan Kepada Masyarakat Sikh. The Sikh Community Seminar in Malaysia, ATMA, National University of Malaysia.

Baumwell, L., Tamis-LeMonda, C. S., \& Bornstein, M. H. (1997). Maternal verbal sensitivity and child language comprehension. Infant Behavior and Development, 20(2), 247-258. https://doi.org/10.1016/s0163-6383(97)90026-6

Clyne, M. (2003). Dynamics of Language Contact: English and Immigrant Languages (Cambridge Approaches to Language Contact) (Illustrated ed.). Cambridge University Press.

Chakrani, B. (2010). A Sociolinguistic Investigation of Language Attitudes Among Youth in Morocco. Amsterdam University Press.

Chaklader, S. (1981). Linguistic Minority as a Cohesive Force in Indian Federal Process. Penguin Random House.

Crystal, D. (2000). Language Death. New York: Cambridge University Press.

David, M. K. (2005). Reasons for language shift in Peninsular Malaysia. Journal of ModernLanguages, 15(1), 1-11.

David, M. K., Naji, I. M. H., \& Kaur, S. (2003). Language maintenance or language shift among the Punjabi Sikh community in the Klang Valley, Malaysia. International Journal of the Sociology of Language, 161, 1-24. https://doi: 0165-2516/03/0161-0001 


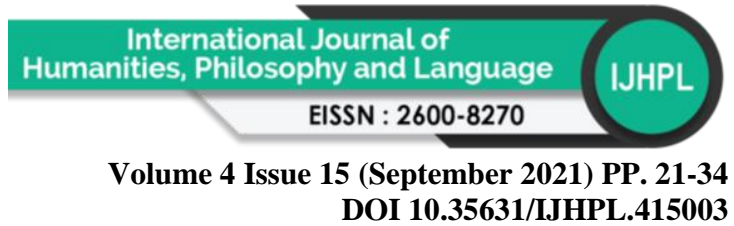

Denzin, N. K., \& Lincoln, Y. S. (2003). Introduction: The discipline and practice of qualitative research. In The Landscape of Qualitative Research: Theories and Issues (2nd ed., pp. 1-28). SAGE Publications, Inc.

Derhemi, Eda. (2002). Protecting endangered minority languages: sociolinguistics perspectives - thematic introduction. International Journal on Multicultural Societies (IJMS), 4(2), $150-161$.

Fase, W., Jaspaert, K., \& Kroon, S. (1992). Maintenance and Loss of Minority Languages: Introductory Remarks, In Maintenance and Loss of Minority Languages (p.3). Amsterdam/Philadelphia: John Benjamins.

Flynn, S., \& Manuel, S. (1991). Age Dependent Effects in Language Acquisition: An Evaluation of Critical Age Hyphothesis. In L, Eubank, Point counterpoint: universal grammar in the second language. Amsterdam, Netherlands: John Benjamins.

Furrow, D., Nelson, K., \& Benedict, H. (1979). Mothers' speech to children and syntactic development: Some simple relationships. Journal of Child Language, 6, $423-442$.

Fishman, J. A. (1991). Reversing language shift: Theoretical and empirical foundations of assistance to threatened languages. Clevedon: Multilingual Matters.

Flick, U. (2014). An introduction to qualitative research (5th ed.). London and Thousand Oaks,CA: Sage.

Gill, S. K. (2014). Language policy challenges in multi-ethnic Malaysia. Netherlands: Springer.

Grbich, C. (2013). Qualitative data analysis: An introduction. London: Sage.

Gleitman, L.R., Newport, E, L., \& Gleitman, H. (1984). The current status of the motherese hypothesis. Journal of Child Language, 11 (1), 43 - 79.

Hale, K. (1992). Endangered languages: On endangered languages and the safeguarding of diversity. Language, 68(1), 1-3.

Hoff-Ginsberg, E. (1991). Mother-child conversation in different social classes and communicative settings. Child Development, 62, 782 - 796.

Hoff, E. (2003). The Specificity of Environmental Influence: Socioeconomic Status Affects Early Vocabulary Development Via Maternal Speech. Child Development, 74(5), 1368-1378. https://doi.org/10.1111/1467-8624.00612

Hammer, S.C. (2011). Changes in language usage of Puerto Rico mothers and their children: Do gender and timing of exposure to English matter? Applied Psycholinguistics, 32 (2), $275-297$.

Holmes, J. (2017). An Introduction to Sociolinguistics (Learning about Language) (5th ed.). Routledge.

Janse, M., Tol, S., \& Hendriks, V. (2003c). The Language Situation and Language Endangerment in the Greater Pacific Area. In Language Death and Language Maintenance: Theoretical, practical and descriptive approaches (Current Issues in Linguistic Theory) (pp. 15-47). John Benjamins Publishing Company.

Joshua Project. (2021). A ministry of Frontier Ventures. Punjabi in Malaysia. https://joshuaproject.net/people_groups/14483/MY

Mesthrie, R. (1999). Fifty ways to say 'I do': Tracing the origins of unstressed do in Cape Flats English. South African Journal of Linguistics, 17(1), 58-71. https://doi: 10.1080/10118063.1999.9724524

Mukherjee, D. (2003). Role of women in language maintenance and language shift: Focus on the Bengali community in Malaysia. International Journal of the Sociology of Language, 161, 103-120. https://doi: 10.1515/ijsl.2003.023 
Naganandhini, N. (2011). "Amma" or "Mommy": The Role of Mothers in Facilitating Intergeneration; Language Transmission in the Singaporean Tamil Community. Final Year Project, School of Humanities and Social Science, Nanyang Technological University.

Pandharipande, R. (2002). Minority matters: issues in minority languages in India. International Journal on Multicultural Societies, 4(2), 213-234.

Pauwels, A. (2016). Language Maintenance and Shift (Key Topics in Sociolinguistics) (1st ed.). Cambridge University Press.

Sallabank, J. (2013). Attitudes to Endangered Languages: Identities and Policies (Illustrated ed.). Cambridge University Press.

Tsunoda, T. (2005). Language Endangerment and Language Revitalization. Berlin/New York: Moutan de Gruyter.

MyGOV - The Government of Malaysia's Official Portal. (2021b). The Malaysian Administrative Modernisation and Management Planning Unit. https://www.malaysia.gov.my/portal/content/30114 Demography of Population

Wai See Ong, T. (2019). The role of human agents for language maintenance of a Chinese community in Malaysia. Applied Linguistics Research Journal. https://doi:10.14744/alrj.2019.73745 